\title{
The leaching and retention of copper lignosulphonate, copper sulphate and copper-EDTA in soil
}

\author{
JoHAN KORKMAN \\ Kemira Oy, P. O. Box 330, 00101 Helsinki 10, Finland \\ PIRKKo Virta \\ Kemira Oy, P. O. Box 171, 90101 Oulu 10, Finland
}

\begin{abstract}
In this work, a comparison is made between four soil types with respect to the leaching and retention of copper in them when it is added in the form of copper sulphate, copper lignosulphonate and copper-EDTA-chelate.

In laboratory tests, the soil samples in lysimeter tubes were fertilised on the surface with amounts of copper corresponding to the amounts used in practice, after which the soils were irrigated with pure water.

The results showed that copper added in EDTA form was leached through the soil columns to some extent during irrigation when the $\mathrm{pH}$ values of the soils had been raised to the 7.0-7.4 level by the addition of lime. The copper added in the form of copper lignosulphonate or copper sulphate was not leached through the columns.

There was no difference in the distribution of copper in the soil columns after eluviation where the different sources of copper were concerned.

The bulk of the copper remaining in the soil was found in the uppermost stratum $2.5 \mathrm{~cm}$ in depth. There was no difference between the four soil types in this respect. When the soil was analyzed immediately after eluviation, the copper retained in it was still in an acetate-EDTA extractable form irrespective of source compound.
\end{abstract}

\section{Introduction}

Particularly where the most precious nutrients are concerned, and for use in especially retentive soils, efforts have been made to find types of nutrient compounds which would be at the growing plants' disposal to as complete an extent as possible. In addition to inorganic fertiliser salts, various kinds of complex compounds have been developed. The aim has been to produce trace element compounds which will remain useful in plants even under difficult conditions, while, on the other hand, their leachability must not be too great.

In this work three different copper compounds were tested: $\mathrm{CuSO}_{4}, \mathrm{Cu}$ EDTA and Cu-lignosulphonate. Copper sulphate is a salt which dissociates into ionic form, Cu-EDTA is a chelate-form, small-molecule complex compound, and copper lignosulphonate is a large-molecule complex formed by organic 
acid; in this complex, several metal ions are attached by different kinds of bonds to the same organic molecule.

EDTA chelates have been used for fertilisation purposes to a certain extent in Finland since comparatively acidic soils are tilled in this country, and of the ligands usually used for chelating (EDTA, DTPA, EDDHA etc), EDTA chelates reveal the best permanence in slightly acidic conditions (NABHAN et al. 1977).

Because of the low raw-material costs involved, lignosulphonate complexes would be advantageous, providing their effectiveness in the soil was adequate. In this project, $\mathrm{Cu}$ lignosulphonate manufactured at the Oulu research institute of Kemira Oy was compared with copper sulphate and commercial Cu-EDTA.

\section{Material and methods}

The most important properties of the four soil types used in the tests are set forth in Table 1.

Table 1. Properties of the soil samples used in the tests.

\begin{tabular}{lllclc}
\hline $\begin{array}{l}\text { Origin of } \\
\text { sample }\end{array}$ & Ruukki & Ruukki & Ruukki & Kirkkonummi & $\begin{array}{c}\text { Analytical } \\
\text { method }\end{array}$ \\
\cline { 1 - 3 } Type of soil & Finesand & Mould & $\begin{array}{c}\text { Carex- } \\
\text { Sphagnum peat }\end{array}$ & Silty clay \\
\hline
\end{tabular}

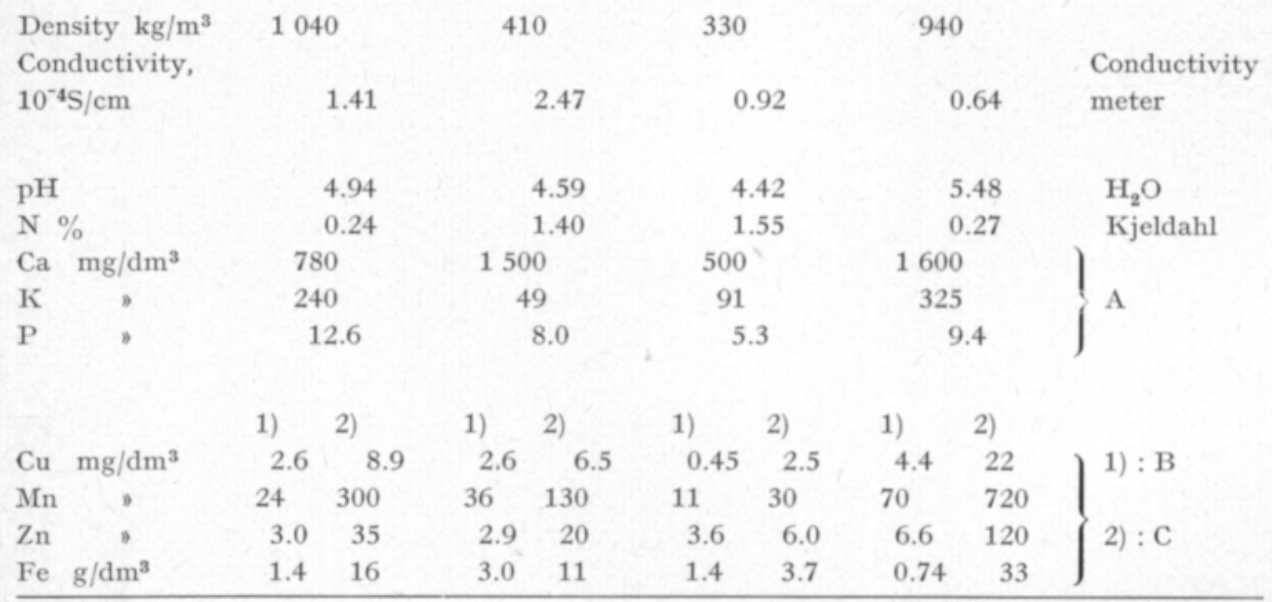

A: From an acid ammonium acetate $\left(0.5 \mathrm{M} \mathrm{CH}_{3} \mathrm{COOH}, 0.5 \mathrm{M} \mathrm{CH}_{3} \mathrm{COONH}_{4}, \mathrm{pH} 4.65\right)-$ extract, $\mathrm{Ca}$ and $\mathrm{K}$ by atomic absorptiometry, $\mathrm{P}$ through the molybdenum blue method spectrophotometrically.

B: From an acid ammonium acetate-EDTA (HAAc + EDTA $=0.5 \mathrm{M} \mathrm{CH}_{3} \mathrm{COOH}, 0.5 \mathrm{M}$ $\mathrm{CH}_{3} \mathrm{COONH}_{4}, 0.2 \mathrm{M}$ EDTAH $\mathrm{Na}_{2}, \mathrm{pH} 4.6$ )-extract by atomic absorptiometry.

$\mathrm{C}$ : The calcined sample (at $500^{\circ} \mathrm{C}$ overnight) is dissolved into a $\mathrm{HNO}_{3}+\mathrm{HF}+\mathrm{HClO}_{4}$ solution. The trace elements in the solution are determined by atomic absorptiometry. 
The soil samples, which had been taken from the surface layer $(0-20 \mathrm{~cm})$ of land under active cultivation, were dried at room temperature, crushed and screened through a $5 \mathrm{~mm}$ screen. One half of each sample was supplemented with $\mathrm{CaCO}_{3}$ lime. The $\mathrm{pH}$ of the limed soil was $7.02-7.35$ at the beginning of the tests.

The soil samples were packed in acrylic plastic tubes, which had an internal diameter of $74 \mathrm{~mm}$ and a height of $350 \mathrm{~mm}$. A vibrator was used to achieve the standard packing density. The volume of the packed soil sample was $1 \mathrm{dm}^{3}$. When the soil layers had been moistened to field capacity, $10 \mathrm{ml}$ of the following solutions were soaked into their surfaces as small drops.

$1 \mathrm{CuSO}_{4}$ solution, $\mathrm{Cu} 125 \mathrm{mg} / 1$

$2 \mathrm{Cu}$ EDTA solution, $\mathrm{Cu} 125 \mathrm{mg} / \mathrm{l}$

3 CuLS solution, Cu $125 \mathrm{mg} / 1$ ( $\mathrm{LS}=$ lignosulphonate)

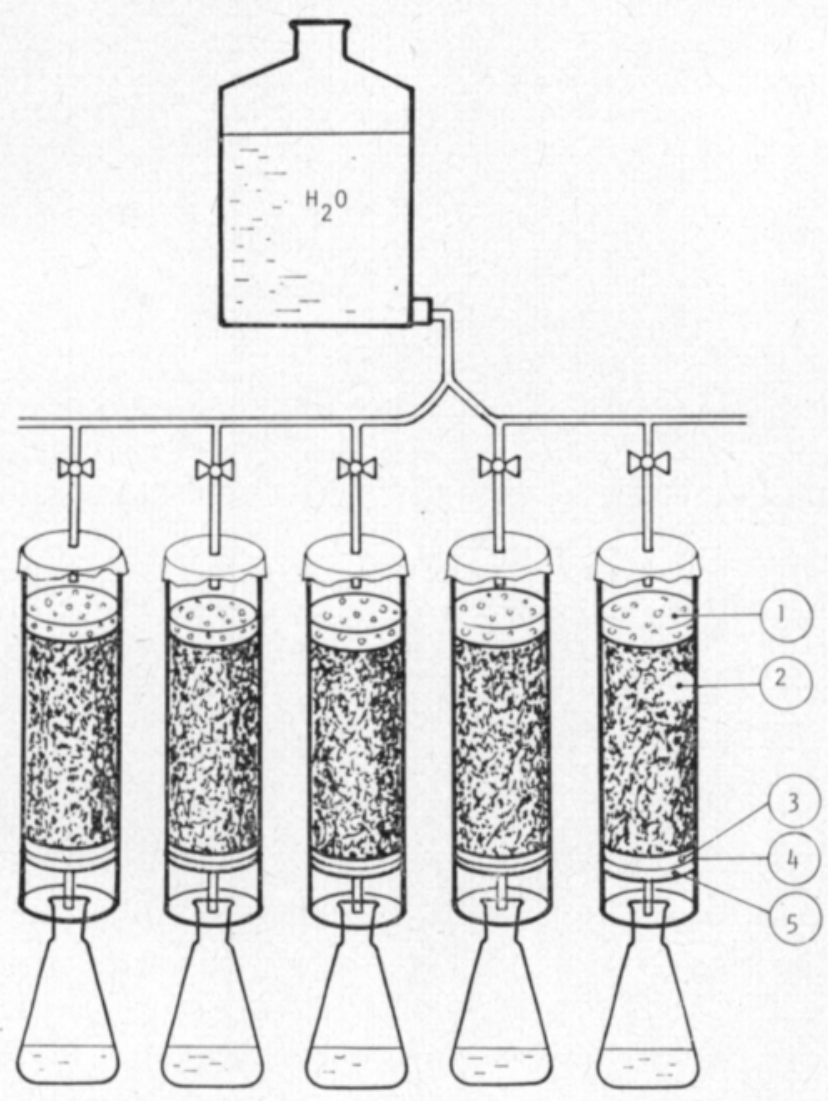

Figure 1. Schematic representation of the test arrangement for the leaching experiments

1. Plastic foam, h $15 \mathrm{~mm}$

2. Soil layer, h $23 \mathrm{~cm}$

3. Slotted, convex Macrolon plate, h $2 \mathrm{~mm}$

4. Rubber seal

5. Concave PVC disc, h $10 \mathrm{~mm}$

The tubes were covered with plastic film. The following day leaching was begun, using distilled water and the test arrangement shown in Fig. 1. The flow rate was $1-2 \mathrm{ml} / \mathrm{min}$, depending on the water transmission capacity of the soil layer; water was not allowed to accumulate in the tubes. The silty 
clay soil, which allowed water to seep through only at a rate of $10 \mathrm{ml} / \mathrm{d}$, was an exception in this respect. $500 \mathrm{ml}$ of percolate was collected in the course of a working day. After four days of leaching, a two-day pause was taken, after which the leaching continued for a further five days. The total amount of water used was $9 \times 500 \mathrm{ml}=4500 \mathrm{ml} .500 \mathrm{ml}$ of water corresponds to $115 \mathrm{~mm}$ of precipitation.

Two days after the last addition of water, the tubes were emptied. The soil columns were each divided into three fractions:

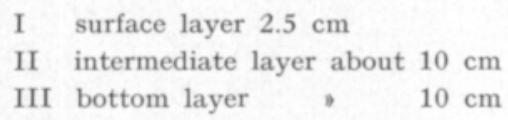

The copper content of each percolate fraction was determined by atomic absorptiometry. The $\mathrm{Cu}$ extractable by the HAAc + EDTA solution was determined in the soil layers by using method B (see Table 1) and the overall copper content by using method $\mathrm{C}$.

Two series of tests were included in the test programme:

Series 1: the addition of solutions $1-3$ to unlimed soils

Series 2: the addition of solutions $1-3$ to lime-enriched soils

Each series comparised three parallel tests. The solutions mentioned above had not been added to the control tubes.

Water percolated through the silty clay sample which had not been enriched with lime at a very slow rate (about $10 \mathrm{ml} / \mathrm{d}$ ). For this reason, the test results for this soil are not completely comparable with those obtained for other soil types.

\section{Results}

Copper leaching

As Table 2 and Fig. 2 show, the $\mathrm{pH}$ has a significant effect on the leaching of CuEDTA only. The influence of the $\mathrm{pH}$ was obvious in mineral soils (finesand, silty clay), through which $\leq 4 \%$ ( $\leq 0.05 \mathrm{mg})$ of the copper added as CuEDTA was flushed when the $\mathrm{pH}$ was about 5 , but at a $\mathrm{pH}$ of about 7 the corresponding figure was $14-22 \% \quad(=0.18-0.28 \mathrm{mg})$. In organogenic soils (Carex-Sphagnum peat, mould), the corresponding figures were $\leq 2 \%$ $(\leq 0.02 \mathrm{mg})$ at $\mathrm{pH} 5$ and $5-10 \%(0.06-0.13) \mathrm{mg})$ at $\mathrm{pH} 7$. In lime- enriched soils, copper added as $\mathrm{CuLS}$ or as $\mathrm{CuSO}_{4}$ was not leached at all, and also in soils to which lime had not been added, there was very little copper leaching. However, the difference when compared with the 0 tests is not statistically significant Leaching was greatest during the first day. 
Table 2. Amount of copper leached out of the soil during the test (mg). $1.25 \mathrm{mg}$ of copper was added to each tube in the form of different $\mathrm{Cu}$ compounds in solution. Significant difference in comparison with the untreated tested with F-test (F).

\begin{tabular}{lccccccc}
\hline \multirow{2}{*}{ Soil type } & 0 test & \multicolumn{2}{c}{ CuEDTA } & & \multicolumn{2}{c}{ CuLS } & \multicolumn{2}{c}{$\mathrm{CuSO}_{4}$} \\
& $\mathrm{mg}$ & $\mathrm{mg}$ & $\mathrm{F}$ & $\mathrm{mg}$ & $\mathrm{F}$ & $\mathrm{mg}$ & $\mathrm{F}$ \\
\hline
\end{tabular}

Finesand

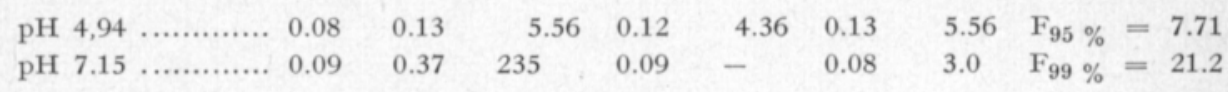

Mould

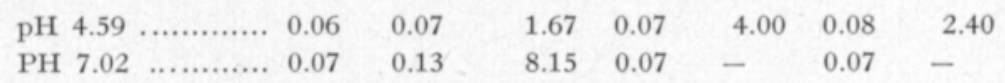

Carex-Sphagnum peat

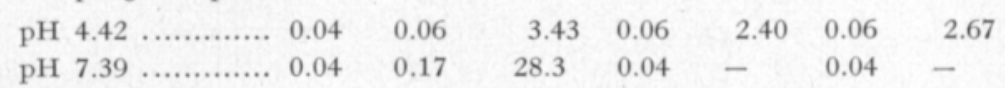

Silty clay

\begin{tabular}{|c|c|c|c|c|c|c|}
\hline $\left.\mathrm{pH} 5.48^{*}\right)$ & .......... 0.015 & 0.015 & & 0.022 & & 0.009 \\
\hline pH 7.35 . & $\begin{array}{lll}\ldots \ldots \ldots \ldots & 0.07\end{array}$ & 0.25 & 202 & 0.07 & - & 0.07 \\
\hline
\end{tabular}

*) no F-test made.

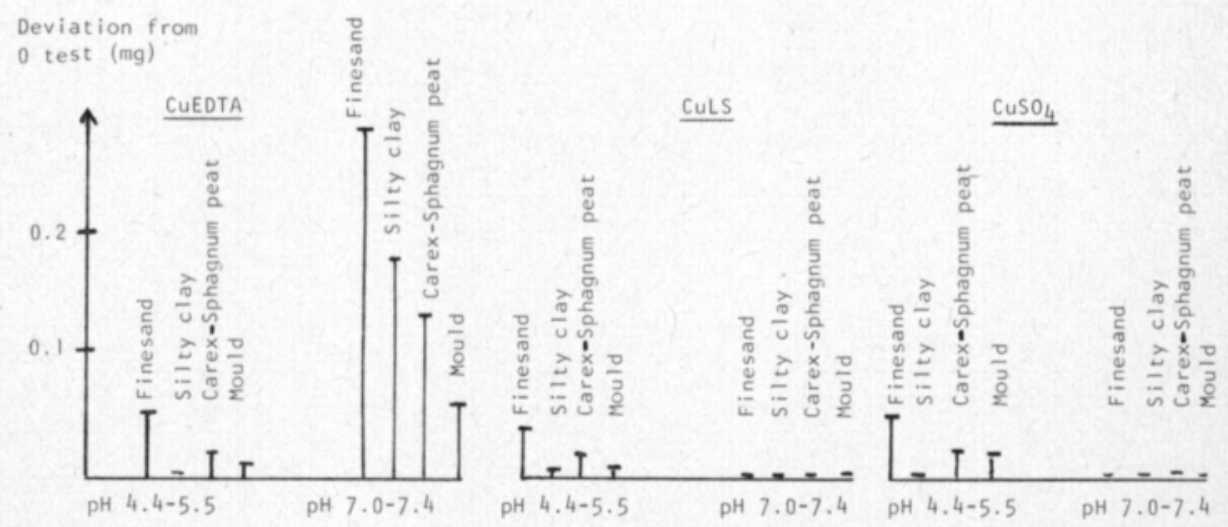

Figure 2. Amount of copper flushed through the soil layer after $\mathrm{Cu}$ had been added in the form of various compounds (1.25 mg/tube), by type of soil.

\section{Copper retention in the soil}

As can be seen from Table 3, the main part of the copper added to the soil remained in the surface stratum. The amount that was carried downwards depended both on the copper compound added and on the type of soil and its $\mathrm{pH}$.

In finesand soil, about $60 \%$ of the CuEDTA added remained in the surface stratum, nearly all of it in a form extractable by a HAAc + EDTA solution; the $\mathrm{pH}$ was not of noteworthy importance. Between $68 \%$ and $75 \%$ of the copper added as $\mathrm{CuLS}$ and $\mathrm{CuSO}_{4}$ remained in the surface stratum when the 
Table 3. Copper concentrations $(\mathrm{mg} / \mathrm{kg})$ in soil fractions after leaching. (Soil strata: $\mathrm{I}=0-2.5 \mathrm{~cm}, \mathrm{II}=$ $2.5-12.5 \mathrm{~cm}, \mathrm{III}=12.5-22.5 \mathrm{~cm})$.

0 test CuEDTA CuLS $\mathrm{CuSO}_{4}$

$\begin{array}{llllllllllllll}1 & 2 & 1 & 2 & \Delta 1 & \Delta 2 & 1 & 2 & \Delta 1 & \Delta 2 & 1 & 2 & \Delta 1 & \Delta 2\end{array}$

Finesand

$\mathrm{pH} 4.94$

$\begin{array}{lrrrrrrrrrrrrrr}\text { I } & 2.2 & 8.2 & 9.6 & 16 & 7.4 & 7.8 & 10.7 & 17 & 8.5 & 8.8 & 10.7 & 18 & 8.5 & 9.8 \\ \text { II } & 2.3 & 8.1 & 3.2 & 8.2 & 0.9 & 0.1 & 2.8 & 7.8 & 0.5 & -0.4 & 2.7 & 8.1 & 0.4 & 0.0 \\ \text { III } & 2.5 & 8.1 & 3.3 & 8.2 & 0.8 & 0.1 & 3.2 & 8.2 & 0.7 & 0.1 & 2.9 & 8.3 & 0.4 & 0.2\end{array}$

$\mathrm{pH} 7.15$

$\begin{array}{lrlllllllllllll}\text { I } & 3.0 & 9.0 & 11 & 17 & 8 & 8 . & 15 & 22 & 12 & 13 & 17 & 23 & 14 & 14 \\ \text { II } & 2.3 & 9.2 & 3.2 & 9.4 & 0.9 & 0.2 & 2.8 & 9.2 & 0.5 & 0.0 & 2.7 & 9.0 & 0.4 & -0.2 \\ \text { III } & 2.5 & 8.9 & 3.2 & 9.2 & 0.7 & 0.3 & 3.2 & 8.8 & 0.7 & -0.1 & 2.9 & 9.5 & 0.4 & 0.6\end{array}$

Silty clay

pH 5.48

$\begin{array}{lcccc}\text { I } & 6.6 & 24 & 12 & 32 \\ \text { II } & 5.9 & 23 & 6.9 & 24 \\ \text { III } & 6.1 & 23 & 6.7 & 23 \\ & & & & \\ \text { I } & 4.9 & 24 & 11 & 32 \\ \text { II } & 4.7 & 24 & 6.2 & 25 \\ \text { III } & 4.6 & 24 & 5.0 & 25\end{array}$

$\begin{array}{llll}5.4 & 8 & 12 & 33\end{array}$

$\begin{array}{llll}5.4 & 9 & 12 & 33\end{array}$

$5.4 \quad 9$

$\begin{array}{ll}1.0 & 1\end{array}$

6.623

$0.7 \quad 0$

6.623

$0.7 \quad 0$

0.60

$\begin{array}{ll}6.723 & 23\end{array}$

0.6

$6.4 \quad 23$

0.3

pH 7.35

$\begin{array}{rrrrrrrrlr}6.1 & 8 & 15 & 37 & 10 & 13 & 13 & 35 & 8 & 11 \\ 1.5 & 1 & 5.0 & 25 & 0.3 & 1 & 5.1 & 25 & 0.4 & 1 \\ 0.4 & 1 & 4.8 & 24 & 0.2 & 0 & 5.2 & 24 & 0.6 & 0\end{array}$

Carex-Sphagnum peat pH 4.42

$\begin{array}{lllllllllllllll}\text { I } & 2.1 & 7.8 & 30 & 43 & 28 & 35 & 34 & 47 & 32 & 39 & 28 & 42 & 26 & 34 \\ \text { II } & 1.9 & 7.3 & 4.2 & 10 & 2.3 & 2.7 & 2.8 & 7.7 & 0.9 & 0.4 & 2.8 & 8.6 & 0.9 & 1.3 \\ \text { III } & 1.8 & 7.4 & 2.8 & 8.8 & 1.0 & 1.4 & 2.6 & 7.4 & 0.8 & 0.0 & 2.9 & 8.3 & 1.1 & 0.9\end{array}$

$\mathrm{pH} 7.39$

$\begin{array}{llllllllllllllc}\text { I } & 2.1 & 7.9 & 31 & 41 & 29 & 33 & 36 & 52 & 34 & 44 & 35 & 49 & 33 & 41 \\ \text { II } & 2.0 & 7.9 & 2.5 & 8.1 & 0.5 & 0.2 & 2.4 & 8.0 & 0.4 & 0.1 & 2.5 & 7.8 & 0.5 & -0.1 \\ \text { III } & 2.1 & 8.2 & 2.9 & 8.4 & 0.8 & 0.2 & 2.4 & 7.7 & 0.3 & -0.5 & 2.4 & 8.1 & 0.3 & -0.1\end{array}$

Mould

pH 4.59

$\begin{array}{lcccc}\text { I } & 5.5 & 15 & 26 & 36 \\ \text { II } & 5.9 & 15 & 7.0 & 17 \\ \text { III } & 5.9 & 15 & 5.3 & 15\end{array}$

$\begin{array}{rrrrrr}20 & 21 & 34 & 44 & 28 & 29 \\ 1.1 & 2 & 6.8 & 15 & 0.9 & 0 \\ -0.6 & 0 & 7.3 & 15 & 1.4 & 0\end{array}$

$\begin{array}{llll}37 & 44 & 31 & 29\end{array}$

$\begin{array}{llll}7.1 & 15 & 1.2 & 0\end{array}$

$\begin{array}{llll}7.4 & 14 & 1.5 & -1\end{array}$

pH 7.02

$\begin{array}{lrlrlrrrrrrrrrr}\text { I } & 6.5 & 16 & 32 & 47 & 26 & 31 & 37 & 54 & 31 & 38 & 39 & 50 & 33 & 34 \\ \text { II } & 6.2 & 16 & 6.7 & 17 & 0.5 & 1 & 6.7 & 18 & 0.5 & 2 & 6.3 & 16 & 0.1 & 0 \\ \text { III } & 6.3 & 16 & 6.8 & 17 & 0.5 & 1 & 6.4 & 17 & 0.1 & 1 & 6.3 & 16 & 0 & 0\end{array}$

$\Delta=$ change in $\mathrm{Cu}$ concentration caused by $\mathrm{Cu}$ addition (compared with 0 test)

$1=\mathrm{Cu}$ amount extractable by HAAc + EDTA solution

$2=$ total copper content

$\mathrm{pH}$ was 5 , but at $\mathrm{pH} 7$ all of it remained. The retained copper remained nearly completely (over $90 \%$ ) in a from extractable by a HAAc + EDTA solution.

In clay soil, about $60 \%$ of the copper added as CuEDTA remained in the surface stratum, where about $30 \%$ of it changed into a form not extractable by the HAAc + EDTA solution. Whether or not lime had been added to the soil had no significant influence on the behaviour of CuEDTA, but this factor 
did have a considerable influence on the behaviour of copper added as CuLS and as $\mathrm{CuSO}_{4}$. When the $\mathrm{pH}$ was 5 , about $70 \%$ of the copper remained in the surface stratum, $40 \%$ of it changing into a form not extractable by the HAAc + EDTA solution. At a $\mathrm{pH}$ of 7 , retention in the surface stratum was complete in the case of CuLS, $85 \%$ in the case of $\mathrm{CuSO}_{4}$; over $70 \%$ of the retained copper remained in a HAAc + EDTA extractable from.

In peat soil, the different copper compounds behaved in nearly the same way. At least $90 \%$ of the copper added was retained in the surface stratum, partially (about $20 \%$ ) changing into a form not extractable by the HAAc + EDTA solution. Whether or not the soil had been treated with lime did not significantly affect propagation.

In mould, CuLS and $\mathrm{CuSO}_{4}$ remained nearly entirely in the surface stratum, remaining almost completely in a form extractable by the HAAc + EDTA solution. Whether or not the soil had been treated with lime did not affect the leaching of CuLS and $\mathrm{CuSO}_{4}$ to any great extent, but it did have a considerable effect on the leaching of CuEDTA: at a $\mathrm{pH}$ of 4.6 , about $30 \%$ of the CuEDTA had penetrated below the surface stratum, but at $\mathrm{pH} 7$ this figure was down to slightly under $10 \%$.

\section{Discussion}

The fixation of nutrient metals into organic complex compounds in soil before they are taken up by plants appears to be quite common, and is perhaps one of the principal reactions in the supply of nutrients. The stability of these humus metal complexes depends on the metallic components in the following way (BROGAN 1966):

$$
\mathrm{Cu}>\mathrm{Ni}>\mathrm{Co}>\mathrm{Zn}>\mathrm{Fe}>\mathrm{Mn}
$$

The stability $(\mathrm{k})$ of a chelate of an organic component and metals depends on the $\mathrm{pH}$ in accordance with the following formula (ADHIKARI and RAY 1966):

$$
\left.k=\frac{[\text { metal chelate }] \cdot\left[\mathrm{H}^{+}\right]}{[\text {metal ion }] \cdot[\text { chelating }} \text { substance }\right]
$$

The lower the $\mathrm{pH}$, the smaller the chelate formation tendency.

Although soil science has mostly focused its study of organometallis compounds on ligands found in soil, it can probably be assumed that artificially created lignosulphonate complexes will behave in nearly the same manner as organic complex formers in the soil (humic acid and fulvic acid).

When a copper sulphonate is used, the copper yields benefits in comparison with those of a dissociating salt, if the LS complex is sufficiently stable to prevent "precipitation".

The retention of lignosulphonate complexes in soil may follow the pattern mentioned by BROGAN (1966) of stability of various metallic humus complexes. Polish studies (SAPEK 1973) have also shown that a CuLS complex, which is regarded as the most stable, is retained in the liquid phase of soil better than LS chelates of other metals.

However, according to SAPEK's studies, the stability of the LS chelates was not sufficient. Only the CuLS complex was slightly superior to sulphatefrom copper in this respect. 
Also in this series of laboratory tests, the difference between $\mathrm{CuSO}_{4}$ and $\mathrm{Cu}$ lignosulphonate proved small in regard to the factors analyzed, but, in contrast to SAPEK's results (1973), the differences compared with CuEDTA chelate were not very considerable. Nor were clear extractability differences in regard to copper retention in the soil found in this study (compare KÄH $\mathrm{ÄI}$ and JAAKKOLA 1977).

Probably it can be assumed that the stability of lignosulphonate complexes under difficult conditions is not adequate to ensure a clear advantage over metallic compounds in salt form.

\title{
REFERENCES
}

AdHIKari, M. \& RAx, J. N. 1966. Stability constants of humic acids and their phosphorylated derivates with $\mathrm{Cu}^{2+}$ and $\mathrm{A1}^{3+}$. J. Indian Chem. Soc. LIII: $238-241$.

Brogan, J. C. 1966. Metal organic complexes in soils. Orbital 1966, 1: 26-31.

КӒнÄRI J. \& JАAKкоLA, A. 1977. A comparison of copper fertilizers in pot tests. (in Finnish). Kehittyvä Maatalous 35:3-6.

Nabhan, H. M., van der Deelen, J. \& Cotronie, A. 1977. Chelate behaviour in saline-alkaline soil conditions. Plant and soil 46: 603-618.

SAPEK, B. 1973. The sorbtion of microelements from microfertilizer solutions through peat soils. (Finnish translation of Polish article). Wroclow Institute of Technology, scientific works published by the Institute of Technology and Mineral Fertilizers, nos. $98-106$.

Ms received January 29, 1979.

\section{SELOSTUS}

\section{Kuparilignosulfonaatin, kuparisulfaatin ja kupari-EDTA:n kulkeutuminen ja pidättyminen maassa}

\author{
JoHAN KORKMAN
}

Kemira Oy, PL 330, 00101 Helsinki 10

PirkKo VirTa

Kemira Oy, PL 171, 90101 Oulu 10

Työssä verrattiin kuparin kulkeutumista ja pidättymistä neljässä maalajissa, kun kupari lisättiin kuparisulfaatin, kuparilignosulfonaatin ja kupari-EDTA-kelatain muodossa maahan.

Laboratoriossa lysimetriputkissa olleet maat lannoitettiin pinnasta pienehköllä, käytännön käyttőmääriä vastaavalla kuparimäärällä, jonka jälkeen eluointi suoritettiin puhtaalla vedellä.

Tuloksista kävi ilmi, että EDTA-muodossa annettua kuparia kulkeutui jossain määrin maapylväiden läpi eluoinnin aikana, silloin kun maiden $\mathrm{pH}$ oli kalkituksella nostettu 7.0-7.4 tasolle. Kuparilignosulfaattina tai kuparisulfaattina annettua kuparia ei kulkeutunut pylväiden läpi.

Kuparin jakautumisessa maapylväissä eluoinnin jälkeen ei ollut juuri eroja eri kuparilähteiden välillä.

Valtaosa maahan jääneestä kuparista löytyi ylimmästä $2,5 \mathrm{~cm}$ paksuisesta kerroksesta. Eri maalajien välisiä eroja ei juurikaan tässä suhteessa ollut. Maahan pidättynyt kupari oli maata heti eluoinnin päätyttyä analysoitaessa yleensä vielä asetaatti-EDTA-uuttuvassa muodossa lähtöyhdisteestä riippumatta. 